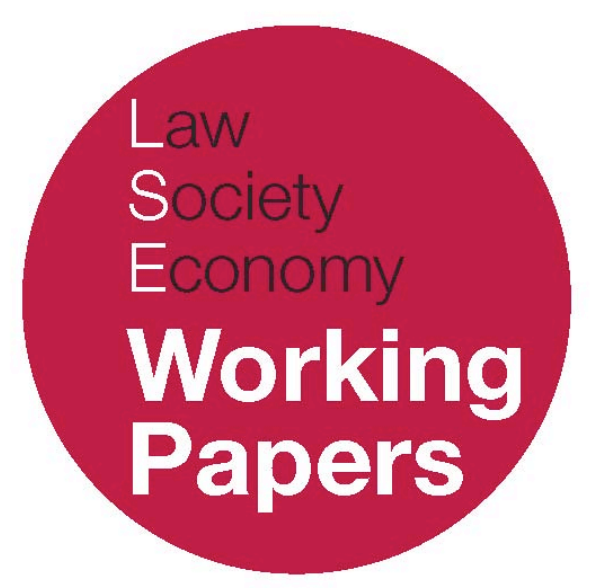

\title{
In Defence of the Common Law Constitution: Unwritten Rights as Fundamental Law
}

\author{
T.R.S. Allan \\ LSE Law, Society and Economy Working Papers 5/2009 \\ London School of Economics and Political Science \\ Law Department
}

This paper can be downloaded without charge from LSE Law, Society and Economy Working Papers at: www.lse.ac.uk/collections/law/wps/wps.htm and the Social Sciences Research Network electronic library at: http://ssrn.com/abstract=1331375.

(C) T.R.S. Allan. Users may download and/or print one copy to facilitate their private study or for non-commercial research. Users may not engage in further distribution of this material or use it for any profit-making activities or any other form of commercial gain. 


\title{
In Defence of the Common Law Constitution: Unwritten Rights as Fundamental Law
}

\author{
T.R.S. Allan*
}

\begin{abstract}
Brudner argues that liberal constitutionalism, or the rule of Law, requires the adoption of a written constitution, regulating the respective powers of court and legislature. In his analysis, the common law constitution is associated with a libertarian paradigm that gives way, in part, to an egalitarian one embodied in a sovereign constitutional text. I argue, to the contrary, that the preservation of the rule of Law, including the protection of liberal rights, does not require a codified constitution, but demands only the consistent application of the correct legal principles to particular cases. Statutes must always be interpreted consistently with such principles: their meaning and validity are alike dependent on their compatibility with fundamental constitutional rights. Demands that cannot be acknowledged as legitimate requirements by an independent moral agent cannot qualify as law.
\end{abstract}

\section{INTRODUCTION}

Alan Brudner's closely-argued, richly-textured and wide-ranging work, Constitutional Goods, provides a striking and original account of the rule of law and its implications for legitimate government. Since the rule of law includes the enforcement of substantive principles of justice, it requires a clear separation of powers between court and legislature. The role of the court is chiefly confined to

\footnotetext{
* Professor of Public Law and Jurisprudence, University of Cambridge. The comments offered by participants at the LSE colloquium, and also those kindly made by Margaret Martin, are gratefully acknowledged. This paper is part of a collection of essays examining important aspects of Constitutional Goods (Oxford: Oxford University Press, 2004), Alan Brudner's magnum opus. It first appeared as a paper presented at a symposium organized by the LSE Legal \& Political Theory Forum and hosted at the London School of Economics on 9-10 May, 2008. This article appeared in the current issue of the Canadian Journal of Law and Jurisprudence (2009) 1. The organizers, Philip Cook and Thomas Poole, would like to thank both the LSE and the LSE Law Department for supporting this event.
} 
pure practical reason, determining what the public reason of the liberal constitution requires. It is the role of the legislative assembly to give its assent to governmental measures that apply the principles of justice to empirical circumstances, where the scope for reasonable disagreement provokes a transition from natural law to political judgment. Judicial review carries no anti-democratic implications because it defends the conceptual boundaries of popular decisionmaking: 'Democracy is not defeated but protected if the court invalidates a law no free person could impose on himself, for the majority has no more authority to pass such a law than an autocrat nor any jurisdiction to decide by fiat a question to which there is a correct legal answer.'1

The idea that a genuine law is one capable of self-imposition, based on sound practical reason or a reasonable extension of such reason to prevailing circumstances of time and place, is central to Brudner's thought. He argues that authority and obligation derive from what he calls the structure of ideal recognition. A claim to authority can be validated only by the free recognition of a subject whose own independence is reciprocally acknowledged: 'Only if the subject who submits can see his independent agency reciprocally submitted to for confirmation of the other's claim does he retain the independence that qualifies him to deliver an objective validation.' ${ }^{2}$ In the context of private law, an ideal transaction is envisaged in which each agent freely accepts the other's end-status as a pre-emptive reason for respecting his liberty on condition that the other do likewise. In the political context, the rule of law affords a right to equality, understood as 'a right to be governed only by laws self-imposable by worthclaiming persons and by executive orders authorised by such laws'. ${ }^{3}$ Such law must embody a conception of public reason which all could endorse: 'A claim of authority is objectively valid only as freely recognised by a subject whose independent self-rule is preserved in its submission; and the subject's self-rule is preserved only if the authority to which it submits is an impersonal Law rather than a personal will.'4

Perhaps the most original and interesting feature of Constitutional Goods is its portrayal of the liberal constitution as a complex, finely-balanced but necessary interaction of contrasting paradigms. Each paradigm represents a stage in the historical progression towards an overarching 'inclusive' conception of liberal constitutionalism. A genuine natural law, adequate to the demands of the 'liberal confidence' - our belief that the individual agent possesses final worth (or endstatus) as a separate individual, distinct from other individuals and apart from social and political ties - must be a composite construction: it will inherit and retain the essential features of Law (or conception of the rule of law) intrinsic to each paradigm. Egalitarian liberals have erred in supposing that anything of value in the preceding libertarian constitution could be simply subsumed within a richer

1 A. Brudner, Constitutional Goods (Oxford: Oxford University Press, 2004) at 213.

2 ibid, at 66.

3 ibid, at 131

4 ibid, at $129-30$. 
paradigm, orientated towards equal citizenship; and communitarians would be mistaken to think that the constitutional goods dependent on the fostering of particular communities are legitimately pursued without regard for the constraints deriving from earlier (partial) conceptions of Law.

If Brudner's arguments work, therefore, we do not need to choose between Hayek and Nozick, on the one hand, and Dworkin and Rawls, on the other - or, at least, we can consistently acknowledge the useful contribution each writer makes to our grasp of the liberal constitution as an integral whole. This is a reassuring conclusion because Hayek and Nozick were surely correct to think that questions of distributive justice arise (as Brudner observes ${ }^{5}$ ) only when society is conceived as an association directed to a common end. Yet it is fundamental to the liberal confidence that the individual cannot be wholly submerged in any common end or sacrificed to any collective good. Hayek was rightly anxious that distributive justice, pursued immoderately, would lead to the elimination of individual liberty and autonomy. Nozick objected, quite reasonably, to Rawls's defence of his difference principle that to treat the talents and abilities of individuals as a common asset, at the service of the political community, is to follow utilitarianism in failing to take seriously the distinction between persons. ${ }^{6}$ There are good reasons to be cautious in our embrace of the claims of liberal equality, which should not be mistaken for the sole content of political morality.

Brudner's separation of the different constitutional paradigms helps to illuminate the concept of law: it reveals the dependence of that concept on competing conceptions of the ideal of the rule of law, as that ideal is exhibited in the context of contrasting moral and political theories. Legal validity is a matter of compliance with the appropriate conception of the rule of law, attuned to the basic premises underlying the relevant constitutional framework. Admittedly, Brudner concedes the gist of Hart's legal positivism: provided that the sovereign rules by general, fixed, and knowable laws, he rules by law even if he does so solely in his own private interest. ${ }^{7}$ Conformity to the canons of procedural legality marks the transition from de facto to de jure authority, regardless of whether the law is just. It does not follow, however, that there is any 'absolute obligation' to obey: an unjust law may be set aside by a court on application. ${ }^{8}$ Moreover, it is a necessary part of the judge's institutional role to reject a law that no conception of public reason could support: the requirements of constitutional justice are implicit in the ruler's de jure authority because such authority, properly exercised, must conform to the true requirements of the rule of law.

Implicit in these conclusions, however, is the view that serious departures from procedural legality deprive a measure of its quality as law entirely: purported laws are sometimes simply void (not merely voidable on application to set aside)

\footnotetext{
5 ibid, at 244.

${ }^{6}$ See F.A. Hayek, Law, Legislation and Liberty (London: Routledge \& Kegan Paul, 1982); R. Nozick, Anarchy, State, and Utopia (New York: Basic Books, 1974); cf n 1 above, 253.

7 n 1 above, 433.

8 ibid, at $433-34$.
} 
even when enacted by due procedure; and in these cases no judicial annulment is required. Yet Brudner sometimes seems reluctant to draw this conclusion. His work is open to the interpretation, at any rate, that the full implications of formal or procedural legality have practical force only once his 'inclusive' conception of liberalism has come to pass. In my view, Brudner sets too much store, in particular, by the existence of written or codified constitutions, drawing in sharp lines where more gentle shading seems to me more apposite. His transition from the free-market libertarian constitution to the social-democratic egalitarian one is overly abrupt, overlooking the manner in which (as I would argue) the former can be adapted incrementally to the demands of the latter - by moral and political argument rather than formal constitutional amendment. He relies, I would respectfully suggest, too much on enacted codes to support what are, on his own analysis, necessary elements of the rule of law, intrinsic to liberal constitutionalism and hence binding (in my view) whether written or unwritten.

In these respects, Brudner may be thought to depreciate the common law constitution, which he largely identifies with the libertarian paradigm - a greatly inferior precursor of the subsequent versions of liberal justice and which is barely, or only reluctantly, a legal order at all. Yet the negative rights of the liberal constitution, if not the positive rights to social and economic benefits, are arguably enforceable by ordinary common law adjudication based on moral reasoning of the kind Brudner's work exemplifies. Admittedly, Brudner's version of liberal justice travels much more deeply into the detailed fabric of the just polity than my own account of the common law constitution. ${ }^{9}$ It is understandable, therefore, that he should complain about the thinness of my own conception of the rule of a law; ${ }^{10}$ and there is force in the objection that the sort of theory that seeks to secure a thin agreement on very abstract principles, such as those found in bills of rights, leaves 'all the important, interpretative work for partisan conceptions of justice'. ${ }^{11}$ Brudner, however, seems to doubt the legitimacy of judicial adherence to the rule of law in the face of current doctrines of legislative supremacy, unconfined by explicit constitutional texts; and this is the question I want to address.

We should not under-estimate the power of the common law constitution to protect fundamental rights, and the central role it ascribes to the individual conscience in testing the moral credentials of law, or rather of what purports to be law but may, on inspection, prove to be an infringement of the rule of law. ${ }^{12}$ Admittedly, Brudner's principle that a genuine law must be capable of selfimposition by an independent agent reflects a similar conception of the rule of law; but arguably he overlooks the power of that principle as an interpretative guide to the content and meaning of positive law. If one may borrow Brudner's

\footnotetext{
9 See Allan, Constitutional Justice: A Liberal Theory of the Rule of Law (Oxford: Oxford University Press, 2001). $10 \mathrm{n} 1$ above, 437. My own conception is a 'decidedly sparse internal morality of law consisting of due process, the political freedoms, and, as far as substance is concerned, an injunction against bills of attainder and against discrimination not justified by some public purpose' (ibid).

$11 \mathrm{ibid}$, at ix.

12 See $n 9$ above.
} 
own idiom (taken from Hegel) of triadic mediation, ${ }^{13}$ the common law court is envisaged as mediating between ruler and citizen: the authority of the legislature is acknowledged by the conscientious citizen whose own reasonable interpretation of the statute, appropriately respectful of his basic rights and legitimate interests, is affirmed by the the court, charged to ensure that the legislative purpose is effected for the public good without unreasonable or unjustified intrusions into liberty.

Brudner complains that, in my own account of constitutional justice, the rule of law requires only the consistent enforcement of some conception of public reason, rather than specifying the true content of that conception. ${ }^{14} \mathrm{My}$ reply, however, is that the common law constitution enforces mainly the essential core of legality, leaving its larger implications to the further development that Brudner describes. Its comparative modesty, however, justifies its more vigorous judicial defence: its prescriptions being more readily distinguished from the matters of judgment and policy properly left to the deliberation of elected representatives, its conceptual claims are harder to deny. In particular, it needs no formal entrenchment in any written code. If it will often be a difficult question whether or not a measure complies with the correct conception of public reason, it will generally be a great deal easier to establish, if that is the case, that a measure fails to conform to any coherent conception of public reason at all.

\section{VALID AUTHORITY AND VALID LAWS}

The liberty rights that compose the libertarian paradigm, and which remain authentic constituents of the inclusive liberal conception, are pre-political: they express or exhibit the ideal relationship between dissociated, free, self-interested individuals. The constitution of liberty makes freedom of choice the fundamental public good; the agent's freedom represents its dignity or inviolable worth and the libertarian conception of public reason is 'the Law under which the free choice of one agent is rendered compatible with the free choice of others'. ${ }^{15}$ Here, then, Brudner follows Kant: 'Any action is right if it can co-exist with everyone's freedom under a universal law.' 16 Accordingly, the rule of law is essentially the rule of private law: 'the libertarian constitution is largely the pre-political (or common-) law of property, contract, tort, and crime'. ${ }^{17}$ The right is wholly prior to the good; liberty rights are absolute constraints on government's pursuit of the common good.

Rehabilitation of the libertarian paradigm is an important corrective to the view that all rights - or all rights entitled to judicial defence - are only the product

\footnotetext{
$13 \mathrm{n} 1$ above, at 214-16.

14 ibid, at 436 .

15 ibid, at 66.

${ }^{16}$ I. Kant, The Metaphysics of Morals, (Cambridge: Cambridge University Press, Eng tran, 1991) at 56.

$17 \mathrm{n} 1$ above, at 67 .
} 
of a specific political arrangement, so that the rule of law is merely the rule of persons exercising the power of a temporary majority (whether at the moment of entrenching a written constitution or, in the absence of such a constitution, at the moment of determining the public interest). ${ }^{18}$ Brudner shows that the fundamental freedoms of thought and conscience, religion, speech, and property are components of the liberal constitution that precede, and hence limit, the power of government: all legitimate authority bows to these rights, suitably characterised, by acknowledging the constraints they necessarily impose on the enactment and execution of positive law.

Ideal recognition, productive of valid obligations, takes the shape of 'mutual cold respect' within the constitution of liberty: 'each agent establishes its sovereignty over a particular domain unilaterally, and each then respects the boundaries thus separately defined'. ${ }^{19}$ However, the civil relations of mutual recognition must be supplemented by a political relationship for reasons of security and stability. The agents become citizens who obey self-imposed laws that embody the relations of mutual respect: 'For the sake of its self-worth, the agent recognises the authority of Law, which reciprocally submits for confirmation of its authority to the self-imposability of its determinations by worth-claiming subjects.'20

Certain freedoms are enjoyed simply because, when properly delimited, their exercise cannot impinge on others' freedom: core freedoms of conscience, speech and association can be defended in this way. ${ }^{21}$ In other cases, there is need for positive law to delineate the boundaries of competing rights. Since principles of law must in these cases be adapted to contingent social conditions, entailing a degree of governmental discretion, in order to be translated into positive laws, the subject's actual assent (or the assent of his representatives) must be added to constructive self-imposition. Rights to a free press, and of free political speech, free association and assembly, and of participation in law-making follow from this requirement. ${ }^{22}$ What follows is a closely-circumscribed sovereignty of the 'common will'. The laws instantiating mutual cold respect limit the scope of public power, which cannot be deployed in contravention of them: commands of the ruler that infringe libertarian rights are invalid. ${ }^{23}$

If measures that contravene the fundamental freedoms are invalid, as violations of the common will, they cannot impose obligations binding in Law; and it must be open to a court (or indeed any citizen or subject) to draw that conclusion in a particular case. Yet Brudner demurs, observing that the 'sovereignty of the common will is one thing, and the method of enforcing that sovereignty another'. ${ }^{24}$ Individual agents have surrendered their liberty to

18 See e.g. R. Bellamy, Political Constitutionalism (Cambridge: Cambridge University Press, 2007).

$19 \mathrm{n} 1$ above, at 67.

20 ibid, at 68 .

$21 \mathrm{ibid}$, at 77 .

$22 \mathrm{ibid}$, at 113 .

$23 \mathrm{ibid}$, at 69.

24 ibid. 
determine and execute Law for themselves to common rulers who now enjoy a monopoly on interpreting Law's demands: 'Since the ruler's interpretative authority has, by virtue of this transfer, become absolute (i.e. untrammelled by a duty of correctness), there is no such thing within the libertarian constitution as the securing of moral rights against the erroneous decisions of rulers by means of their entrenchment in a supreme positive law guarded by a judiciary accountable to a standard of correctness. ${ }^{25}$

The division of powers between the branches of government is, Brudner explains, a matter of prudence rather than theoretical necessity. The first ten amendments to the United States Constitution provide an instance of entrenchment of the libertarian paradigm; but absolute parliamentary sovereignty is an equally available option. And as both Kant and Dicey appear to agree, even if the legislature may violate the rights it is supposed to enforce, it cannot exceed its authority in doing so: 'Its opinions (and its opinions alone) have the force of law. ${ }^{26}$ The subject may protest that the legislature has wronged him but he may not disobey. The sovereignty of Law has collapsed, on this view, into the despotism of the ruler: 'The individual has submitted to the law-making of a ruler, but the ruler has not submitted its laws to a test of self-imposability, for it claims that valid law is one thing and Law another.'27

No doubt, Brudner here conveys the essence of the libertarian paradigm; but one may question whether his bleak encapsulation does not come close to contradicting the idea of the common will, as earlier presented, and thereby exaggerating the citizen's predicament. We are not dealing here with a Hobbesian sovereign whose will determines right and wrong. Brudner argues that the legislator 'acknowledges that there is a right independent of its beliefs but not that it has a duty to act in ways that are objectively conformable to it'. Would it not be more accurate to say that, though acknowledging its duty to act consistently with justice, the legislator denies its accountability to others for the duty's strict performance? The scope for reasonable divergence between Law and the legislator's honest view of Law's requirements must depend on all the circumstances; what is wholly unreasonable calls good faith into question. As Brudner concedes, the legislator may not intentionally violate rights without absolving the subject of its duty of obedience, and 'an egregious violation without plausibly justifying reasons will no doubt signal intention'. ${ }^{28}$ And we should not distinguish too sharply between the content of positive law and its validity: even the commands of the sovereign must be interpreted before they can be confidently applied.

The enactments of a sovereign parliament, accordingly, will normally be construed as conforming (or intending to conform) to the basic freedoms, insofar as the content of those freedoms can be accurately discerned by clear conceptual

\footnotetext{
25 ibid, at $69-70$.

$26 \mathrm{ibid}$, at 143 .

27 ibid.

28 ibid.
} 
analysis; to interpret legislation otherwise would show disrespect by treating the legislature as oblivious of its constitutional duties. As Brudner fairly observes, against Coke's veneration of Parliament as 'the highest and most honourable and absolute Court of Justice in England' must be set his warning that an Act of Parliament against 'common right and reason' would be annulled as not (when properly examined in the context of application) representing Parliament's true intention. ${ }^{29}$ Dicey's absolutism was similarly qualified by his insistence that the subjection of statutes to judicial interpretation ensured the preservation of the rule of law. It was impossible for Parliament, for example, to bestow dictatorial powers on the executive in practice because even the 'most arbitrary powers' could be brought under judicial control: 'Powers, however extraordinary, which are conferred or sanctioned by statute, are never really unlimited, for they are confined by the words of the Act itself, and, what is more, by the interpretation put upon the statute by the judges. ${ }^{3} 0$

When, however, is the content of the fundamental freedoms conceptually clear? No doubt, the application of these freedoms in concrete instances is often a matter of reasonable controversy, limiting the scope for argument over the validity of statutes. Nonetheless, in some cases correct answers will be straightforwardly deducible by competent analysis of the libertarian constitution or even of the inclusive conception itself. Brudner's account of freedom of conscience provides a good example. The common will precludes the use of public power to force anyone to profess or renounce a religious belief, or to enforce any form of worship or religious observance; and the right of immunity to any such exercise of power is a feature of liberal constitutionalism generally, because the coercion of conscience is 'an attempt to subdue the idependent mind needed to validate the authority of any conception of the public'. ${ }^{31}$ If, then, there is any principle of liberal constitutional law that enjoys unconditional validity, it is the right of the inward mind and conscience to be independent'.32 The requirement that school pupils should salute the American flag and recite a pledge of allegiance, in breach of their religious convictions, was therefore unconstitutional and, hence, invalid. In Barnette, the Supreme Court overruled its earlier decision that the law impugned was valid, affirming thereby that the dissentients had been entitled to disobey in spite of the court's previous decision to the contrary. ${ }^{33}$

We need to distinguish clearly between the principles of Law, capable of conceptual derivation from the libertarian paradigm, and the positive laws enacted to implement these principles through more precise standards or rules. As Brudner explains, principles of Law directly deducible from the common will are

\footnotetext{
${ }^{29}$ Compare Sir Edward Coke, Institutes of the Laws of England (London, 1628), I, 109-110, with Dr Bonham's Case (1609) 8 Co Rep 107, at 118.

30 A. V. Dicey, Introduction to the Study of the Law of the Constitution, 10th ed (London: Macmillan, 1959) at 413

$31 \mathrm{n} 1$ above, at 83 .

32 ibid.

33 West Virginia State Board of Education v Barnette 319 US 624 (1943); see R. Dworkin, Taking Rights Seriously (London: Duckworth, 1977) at 213 - 14.
} 
capable of constructive self-imposition, logically entailed by the true requirements of liberty: 'Because the common will is the matrix of valid worth-claims, the subject, in obeying its a priori determinations, obeys only its own reasonable will. ${ }^{34}$ Even if such principles must be adulterated by fact and discretion before being transmuted into positive law, they continue to rule out positive laws inconsistent with them: 'No doubt, they can and must meet certain theshold tests of self-imposability before they can be considered for ratification - tests of both form and content. Formally, they must be knowable and general in their application, imposing no asymmetrical obligations; and their content must not violate the a priori determinations of Law that are constructively self-imposed....'35

Accordingly, the political rights correlative to the duty on the legislator to conform to the requirements of valid authority are, in principle, self-enforcing. Their breach will often be self-evident, undermining any claim to obedience of infringing measures. It cannot be the case that invalidity is apparent only when, requiring actual ratification of their contingent content, measures have not been duly enacted. If I have 'a moral obligation to obey positive laws only insofar as they have been submitted to the consent of the ruled, which is to say that I have a right to a judicial remedy of certiorari saying that I had a liberty to disregard a law enacted without consent', 36 the same must apply, mutatis mutandis, to positive laws that do not meet the theshold tests of self-imposability. Brudner appears to reach similar conclusions in his discussion of justiciability, arguing that certiorari gives expression to a juridical relationship existing independently. ${ }^{37}$ An illegitimate attempt to hinder the exercise of freedom of speech may be met by civil disobedience, the justifiability of which the court's order confirms. The ruler owes the subject a duty to respect his freedom of speech as a complement of his authority: 'Breach of the duty delegitimates the breaching act as an expression of authority, frees the subject from the obligation to obey, delegitimates any force used by the ruler to enforce his command, and legitimates any force used to resist the ruler's. 38

The formal tests of valid law are surely the most basic components of the rule of law, in the sense that failure to meet these standards disqualifies a measure outright. Fuller demonstrated that a legal system requires, at a minimum, the existence of ascertainable general rules that can serve as effective guidelines for action: there must be, in addition to generality itself, publicity, intelligibility, constancy, and non-retroactivity. ${ }^{39}$ And we can deduce from Fuller's work that conformity to the standards of procedural legality is a requirement of the respectful treatment owed to the citizen by any constitutional ruler, who acknowledges the distinction between the rule of law and mere rule by law (in the weakened sense of ad hoc decree). Brudner confirms and amplifies this conclusion

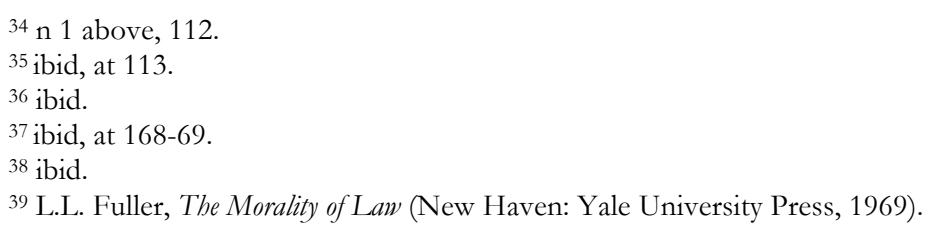


by explaining that ruling by general and knowable laws is a condition of valid authority 'because it is a condition of the ruler's obtaining independent confirmation of his claim through the subject's autonomously applying the ruler's commands to himself. 40 Compliance with the minimum requirements of procedural legality is a critical element of the rule of Law, understood as an appropriate conception of public reason, whereby authority is a product of ideal mutual recognition between ruler and subject, or government and governed.

If a right to 'equality before the law', or the rule of law, is the right to be governed by some conception of public reason, the requirement of legality or generality is protected within the libertarian constitution as the right to 'equal protection of the law'. ${ }^{41}$ It establishes, inter alia, that there is 'no obligation to obey penal laws or executive orders that restrict liberty unqually'. ${ }^{42}$ Bills of attainder and ad hoc decrees are invalid, as are penal laws that target particular individuals or groups even if it is not their purpose to victimise such people. No one could recognise a greater liberty for others than they recognise for him without compromising the independence that qualifies him to consent to such a measure. A statute prohibiting Communist Party members from serving as officers of trade unions is invalid as a bill of attainder even if an empirical correlation can be shown between membership of the Communist Party and a propensity to incite illegal strikes. ${ }^{43}$ As Brudner emphasises, moreover, the prohibition on bills of attainder is not only a feature of the libertarian paradigm but, as one would expect, a fixture of the inclusive conception, or liberal constitutionalism simply.

When, moreover, the defect is apparent on the face of a bill or measure, so that its abrogation of Law is proclaimed in its implicit assertion of authority, there is no need of a Constitutional court, exercising any special powers, to strike it down. It is self-evidently null and void and everyone affected - or who might be affected if it were valid - can act accordingly. It is no different from a bill that has not been enacted by the properly constituted legislature with due procedure: it is a purported intrusion into liberty which lacks any legal consequences. Law, then, has its own intrinsic form, whether or not governmental powers are conferred or limited by a written constitution.

Accompanying the right to disregard a measure that, on its face, infringes the principle of constructive self-imposition must be a right to point out the deficiency, even if in consequence others also choose to disobey. Brudner affirms the existence of a broad right to political speech. It extends to speech that advocates the forcible overthrow of rulers who have subverted the constitutional order, and to speech that impugns the integrity or competence of a public official. ${ }^{44}$ New York Times v. Sullivan was correctly decided because the libel exception to the right to civil speech has no application to political speech. There

$40 \mathrm{n} 1$ above, at 40 .

$41 \mathrm{ibid}$, at 132 .

42 ibid.

43 United States v Brown 381 US 437 (1965); see n 1 above at 133.

${ }^{44} \mathrm{n} 1$ above, at 116-17. 
is no right, however, to speech inciting the forcible overthrow of rulers who defer to the constitutional means for scrutinizing or replacing them, or for speech that counsels disobedience to a law the speaker thinks unconstitutional but which has obtained the assent of the popular assembly. ${ }^{45}$ However, the fact that a measure enjoys the assembly's approval does not show that it has the status of law, properly understood. If it fails the threshold tests for law, supplied by the basic conceptual requirements of liberal justice, it remains a measure that merely purports to be law. There is no threat of anarchy because such speech does not advocate the repudiation of law: it denies that what purports to be law is truly a law imposing any genuine obligation of obedience. The speaker reclaims a power of individual law-determination inconsistent with the idea of Law's rule only when, in addition to the approval of the assembly, the measure impugned meets the conceptual requirements necessary for constructive self-imposition. When a measure is believed to fall short of those requirements it must be within the civic duty of any citizen to call attention to the matter; and he does not act improperly merely because a court concludes, if it does, that he has made a conceptual mistake. ${ }^{46}$

\section{THE EGALITARIAN CONSTITUTION}

Within Brudner's scheme of thought the break from the libertarian to the egalitarian constitution is inaugurated by the adoption and entrenchment of a written constitutional code. By contrast with the libertarian paradigm, the egalitarian conception guarantees the conditions of self-authorship and self-rule for all: Law includes the provision of those goods necessary for individual autonomy. Instead of the authority of practical reason being alienated to the sovereign, individuals are born to citizenship: 'a common practical reason specified in the idea of equal moral membership governs public life from the beginning'. ${ }^{47}$ Now the rulers have a duty to be right in determining whether they have properly secured the conditions of autonomy; and since they should not be judges in their own cause on the matter they must entrench the constitution of equality in supreme positive law, enforced by an independent judiciary: 'As a condition of the self-imposability of the constitutional order, entrenchment is a duty going with authority. ${ }^{3} 8$

\footnotetext{
45 ibid.

46 Brudner objects to the distinction I have made between the conscientious inciter and someone who counsels disobedience for personal gain (n 9 above, at 107): he objects that motive is irrelevant since both inciters threaten to displace an objective order by a subjective will and hence the dissolution of Law's rule: $\mathrm{n} 1$ above, at 117, n 12. When we insist on compliance with the conditions of Law's rule, objectively determined, however, we can distinguish between what is in substance an appeal to Law, correctly understood, and incitement of admitted law-breaking (for personal gain) on the other.

$47 \mathrm{n} 1$ above, at 164 .

48 ibid.
} 
Brudner considers the objection that, if Law is truly sovereign, the judges must possess inherent authority to enforce the 'constitutional order of values' against the legislature without explicit authorisation by a written constitutional text. He defends the requirement of entrenchment, nevertheless, on the ground that the judges must defer to the reasonable judgment of rulers on matters of policy: 'it is a matter of judgment and not a priori knowledge whether a statute promoting a constitutional good has limited rights more than necessary to achieve the good'. ${ }^{49}$ And judges cannot be judges in their own cause as to whether or not they have deferred to the legislature when deference was due. A written constitution can enable the elected assembly to recover jurisdiction from a judiciary that has usurped it. But what if the assembly overrides a judicial invalidation of a statute that violates the conditions of autonomy or equal moral membership? Brudner's answer is that the assembly must be exposed to the political costs of misusing its powers. He endorses, therefore, an arrangement similar to section 33 of the Canadian Charter of Rights and Freedoms, though without the power of prospective immunization of a statute from judicial invalidation or the power to declare laws operative notwithstanding certain provisions of the Charter (rather than notwithstanding judicial declarations of invalidity).

The latter powers under section 33 of the Charter are incompatible with constitutionalism: these features of the Canadian override 'seem to reproduce at the level of judicial review the libertarian tension between the common-law constitution and legislative despotism, reflecting as they do a half-hearted entrenchment of basic rights'. ${ }^{50}$ The purpose of an override (Brudner explains) is to allow the assembly to reclaim jurisdiction wrongly invaded by the court, not to permit the substitution of a view of Law's requirements contrary to that of the court. Nevertheless, these are rather fine distinctions which may be hard to apply in the heat of battle over the legitimate content of fiercely-contested legislation. A resolution should clearly reflect the proper scope for reasonable disagreement that further argument and analysis, aided and informed by the popular and legislative debate, reveals. But the ordinary process of legislative amendment, followed by judicial interpretation in particular cases, may well be a superior mechanism for resolving conflicts over the border between Law and public policy. The evidence suggests that any connection between the precise terms of a bill of rights and the nature and quality of political reactions to judicial review may be somewhat tenuous in practice. 51

The idea that the ultimate safeguard for fundamental rights is the power of public opinion is itself a recurrence to the old libertarian constitution, in which Law ultimately surrenders to the vagaries majoritarian politics. It was recently restated by Lord Hoffmann, affirming that 'parliamentary sovereignty means that Parliament can, if it chooses, legislate contrary to fundamental rights', there being

$49 \mathrm{ibid}$, at 165.

$50 \mathrm{ibid}$, at 284.

51 See J.L. Hiebert, 'Parliamentary Bills of Rights: An Alternative Model?’ (2006) 69(1) MLR 7. 
only political rather than legal constraints on legislative power. ${ }^{52}$ Admittedly, fundamental rights cannot be overridden by 'general or ambiguous words' because the risk is too great that 'the full implications of their unqualified meaning may have passed unnoticed in the democratic process'. The court needs to be confident that any infringement of rights is deliberate and considered, so that responsibility can be pinned on the legislature for the resulting injustice. The 'principle of legality' means only that 'Parliament must squarely confront what it is doing and accept the political cost'. ${ }^{53}$

This is a questionable understanding of the true common law constitution, however. In a matter concerning (as in Simms) the rights of prisoners, the 'political cost' of interference with constitutional rights may be very small; and yet Hoffmann contemplated the abridgement, without proper justification, of common law rights to freedom of speech and of recourse to legal process to overturn a mistaken conviction. Could such abdication of responsibility by the judiciary be accepted as consistent with the rule of law? In practice, basic principles are honoured by seeking an appropriate reconciliation between public purpose and private right - seeking an interpretative solution that can command general assent as a reasonable construction of the statute in all the circumstances of the particular case. The graver the threat to fundamental rights in the particular case, and the weaker the justification for the infringement threatened, the more confidently a judge can conclude that an 'unqualified' construction was not intended or envisaged. Since the whole foundation of the common law constitution, in its present stage of development, rests on the assumption that Parliament intends the rule of law to be upheld by courts and public officials, it is right to give fundamental rights their appropriate weight in resolving the precise meaning of the statutory command. The assumption that 'Parliament legislates for a European liberal democracy founded on the principles and traditions of the common law'54 places powerful contraints on what statutory language can be taken to permit or require. Lord Hoffmann came closer to the reality, then, when suggesting that British courts, while formally granting legislative supremacy, apply 'principles of constitutionality' akin to those applicable in countries 'where the power of the legislature is expressly limited by a constitutional document'. ${ }^{55}$

It should occasion no surprise, therefore, that legislative provisions apparently precluding the admission of evidence of the complainant's previous sexual experience, in a trial for a sexual offence, were accorded a non-literal reading: such evidence, though inadmissible for the purpose of embarrassing or intimidating the complainant, could be received where it was necessary to ensure a fair trial. ${ }^{56}$ Since the rule of law cannot countenance the state's prosecution of unfair proceedings against the accused, the statute must be interpreted accordingly.

\footnotetext{
52 R v Secretary of State for the Home Department, exp Simms [2000] 2 AC 115 at 131.

53 ibid.

${ }^{54} \mathrm{R} v$ Secretary of State for the Home Dept, exp Pierson [1997] 3 WLR 492 at 518.

$55 \mathrm{n} 52$ above.

56 See Rv $A$ (No 2) [2001] UKHL 25, [2002] 1 AC 45.
} 
Lord Steyn thought it right 'to proceed on the basis that the legislature would not, if alerted to the problem, have wished to deny the right to an accused to put forward a full and complete defence by advancing truly probative material'. ${ }^{57}$ Admittedly, the judges drew support from the Human Rights Act 1998, incorporating Article 6 of the European Convention on Human Rights into English law, doubting that 'ordinary methods of purposive construction' would suffice. Since, however, the Act purports to preserve parliamentary sovereignty, it leaves the common law constitution fundamentally intact. The requirement in section 3 that legislation should be construed compatibly with the Convention in so far as it is 'possible to do so' is essentially (if controversially) a restatement of common law principle, as regards the protection of common law rights. What is 'possible', moreover, will reflect what is necessary: it is a judgment about the demands of the statutory provision in context - in the light of the rights and interests affected - rather than an observation about the literal (acontextual) meaning of words. ${ }^{58}$

The Canadian Supreme Court reached similar conclusions in Mills. ${ }^{59}$ The previous legislative regime, restricting disclosure of the alleged victim's therapeutic records in cases of sexual assault, had been held to violate the rights of the accused to a fair trial. ${ }^{60}$ Although the replacement statute also imposed restrictions on disclosure, the court was able to interpret them in a manner that preserved the accused's right to make 'full answer and defence' (a requirement of fundamental justice guaranteed by section 7 of the Charter). The court acknowledged scope for legislative amendment of the common law, within the boundaries the Charter provided, and applied a presumption that Parliament intended to comply with fundamental rights. It was sufficient that the trial judge enjoyed the requisite latitude, after taking account of a range of specified policy considerations, to safeguard the defendant's procedural rights: 'Parliament must be taken to have intended that judges, within the broad scope of the powers conferred, would apply [the pertinent section] in a constitutional manner - a way that would ultimately permit the accused access to all documents that may be constitutionally required.' 61

In one sense, Brudner is right to reject an account of the Charter override as encouraging dialogue between branches of government: insofar as there are correct answers to questions of rights it is for the court to declare them. In another sense, however, the Charter provides for the accommodation between judicial and legislative perspectives that the distinction between law and policy, or pure practical reason and legislative discretion, requires. For similar reasons, the

\footnotetext{
$57 \mathrm{ibid}$, at para 45.

58 See further Allan, 'Parliament's Will and the Justice of the Common Law: The Human Rights Act in Constitutional Perspective' (2006) 59 Current Legal Problems 27. See also Secretary of State for the Home Dept $\mathrm{v}$ MB [2007] UKHL 46, [2007] 3 WLR 681 (control order proceedings, under Prevention of Terrorism Act 2005 , construed as takin $g$ effect only where it was consistent with fairness for them to do so).

${ }^{59} \mathrm{R}$ v Mills [1999] 3 SCR 688.

${ }^{60} \mathrm{R}$ v O'Connor [1995] 4 SCR 411.

61 [1999] 3 SCR 688 at 747.
} 
notion that the Human Rights Act stimulates dialogue between courts and Parliament over the correct meaning of the Convention rights must be treated warily. ${ }^{62}$ The courts are not, as Hickman observes, merely a 'privileged pressure group whose function it is to raise good reasons why a litigant's interests should be respected'.63 The courts should make a 'declaration of incompatibility', under section 4, only in the last resort - when, if ever, it is truly impossible to interpret a provision consistently with the Convention (for example, because the Convention envisages the operation of institutional safeguards that only Parliament can establish ${ }^{64)}$. There is nevertheless scope for dialogue in the more limited sense that courts and legislators must find an acceptable compromise, granting constitutional rights their due while making necessary adjustments to give effect to legitimate public interests (constitutional goods). ${ }^{65}$ As Mills shows, a fundamental right, even on its correct definition, may permit a variety of avenues to secure its vindication, along with other fundamental rights and legitimate public interests. ${ }^{66} \mathrm{~A}$ judicial usurpation of the proper role of the legislature will normally provoke a reassertion of the parliamentary will, forcing the courts to reconsider the soundness of their own analysis - if only to forestall constitutional deadlock or breakdown.

In the last resort, however, it must be for the court to furnish adequate protection, in the particular case, for the litigants' fundamental rights; for the court cannot contravene Law's prescriptions without contradicting its function and thus undermining the constitution. The interpretative power enjoyed by judges under the common law constitution seems adequate for this purpose. An enacted bill of rights with a formal override encourages the idea (notwithstanding Brudner's warning) that basic rights can be legitimately, if temporarily, set to one side or recast to match current popular opinion. Nor is the lack of a power formally to strike down a statute necessarily a handicap for the common law court: it is less provocative - more conducive to institutional comity and cooperation - to interpret a provision restrictively, allowing it to operate where it can do so without impermissible violation of rights. The distinction between restrictive interpretation and general invalidity is essentially a matter of degree: it is sufficient for the protection of basic rights that a provision should not be applied in any case where those rights would in consequence be impermissibly infringed. Just as the Human Rights Act is mainly a statutory confirmation of the common law constitution, so the Canadian Charter is only a reaffirmation of the intrinsic requirements of Law. In neither case is the constitutional role of the courts fundamentally altered; nor is the relationship between courts and legislature significantly modified. It is precisely

62 See T.R. Hickman, 'Constitutional Dialogue, Constitutional Theories and the Human Rights Act 1998' [2005] Public Law 306.

63 ibid, at 309.

${ }^{64}$ See e.g. Re S (Minors) (Care Order: Implementation of Care Plan) [2002] UKHL 10, [2002] 2 AC 291; see n 62 above, at 332-35.

65 See T.R.S. Allan, 'Constitutional Dialogue and the Justification of Judicial Review' (2003) 23 Oxford Journal of Legal Studies 563.

${ }^{66}$ See esp. [1999] 3 SCR 688, 712. 
the great strength of Brudner's work to show how Law's prescriptions are, in their general nature, independent of contingent institutional frameworks.

It is an interesting question whether the common law constitution can embrace the positive rights that guarantee the conditions necessary for autonomy basic provision for food, housing, medical care and education. No doubt, judicial orders to enforce such rights would be unavailing in the absence of a legislative scheme, whether or not bolstered by formally entrenched provisions. Brudner argues persuasively that a ruler's affirmative action is lawfully compellable if his duty to perform it is complementary to his valid authority. ${ }^{67} \mathrm{It}$ is part of the libertarian constitution itself that the sovereign must provide the administrative apparatus needed to protect rights to life, liberty, and property. Under the egalitarian constitution, far more is required. A judicial remedy of mandamus can command provision of the material bases of self-rule and self-authorship, or courts may read into an existing scheme necessary entitlements that it would otherwise lack: 'Since it would be lawful to resist with civil disobedience the force of a ruler who refused to comply with such a remedy, the affirmative duty to promote the common welfare is no less part of legal morality than a duty not to interfere with the freedom of speech or the duty to protect the subject's civil rights. ${ }^{6} 68$

Brudner is also surely right to repudiate the 'false dichotomy between justiciable negative rights and non-justiciable positive rights'. Problems of indeterminacy in the content of positive rights can be met by a reasonableness standard of review, allowing the legislature to determine the allocation of resources that best promotes the common welfare. Provided that the allocation is reasonable, the approval of the legislature signifies an allocation that all free subjects could endorse and is therefore a valid determination of Law: 'But an unreasonable allocation is by definition not one that all could make, and so, in mandating a correction, the court does nothing but hold the legislature to the idea of moral membership and the rule of Law, just as it does when protecting negative rights. ${ }^{69}$

The conclusion one might draw is that the egalitarian constitution, like its libertarian counterpart, can be nurtured and developed by the common law, though only in harmony and co-operation with the elected legislature. The comparative modesty of the positive material conditions of self-rule and selfauthorship, as Brudner explains them, makes their assertion as a necessary component of Law both attractive and plausible. Once, moreover, positive rights are embodied in legislation, signalling general assent to the egalitarian paradigm, it is only a small step for courts to require that existing statutory schemes should meet a standard of reasonableness as regards the protection of the common welfare. The possibility of judicial over-reaching cannot be entirely dismissed; but

\footnotetext{
${ }^{67} \mathrm{n} 1$ above, at 169.

68 ibid.

$69 \mathrm{ibid}$, at 172.
} 
in practice the courts' dependence (in this sphere above all) on the continuing goodwill and assent of executive and legislature greatly diminishes the danger.

\section{CONCLUSION}

This paper has sought to clarify the court's role, under the common law constitution, as mediator between citizen and state. Its power to enforce the rule of law stems, not from any entrenched or enacted written constitution, but from the general principles that determine when the citizen's assent to the state's demands are truly given - whether by explicit acknowledgement of their legitimate claims on conscience or by virtue of their intrinsic reasonableness, as embodiments or expressions of a genuine common good. Although for practical purposes the court must finally determine the legitimacy of the state's exercise of force, in any particular case, it represents (or should represent) the judgment that the conscientious citizen himself would reach on the matter in question. It is, in the first instance, the citizen's prerogative to determine the justifiability of compliance with the state's demands; and since he may properly resist departures from the rule of law, he is entitled in appropriate cases to a judicial remedy affirming that offending measures are void ab initio, incapable of affecting his legal rights. Breaches of his fundamental rights are not healed or excused by legislative sanction, except in those cases where infringements can be truly justified as being necessary for the common good. I interpret Brudner's work as supporting these basic ideas and elaborating their implications.

Although the familiar codes of rights of modern constitutions strengthen the judicial enforcement of the rule of law, they do not in themselves delineate the content of Law - for Brudner shows that the principles are prior to, and independent of, the enacted formulas in which they are contingently expressed. In essence, the written constitutions of liberal democracy summarise the progressive development of the common law. The interaction of legislature and judiciary, accordingly, is more a matter of working out the intrinsic requirements of Law, within the immediate constraints of present circumstances, than of following the prescriptions of a constitutional text.

Admittedly, we are warned by Brudner's Preface not to confuse ideal theory with the constitutional law tied to a particular text, national history, or body of legal precedent. ${ }^{70}$ The theory of liberal constitutionalism presented is therefore 'unsuitable for transcription into judicial reasoning, which must manifestly observe these constraints . . . lest the rule of law shade into judicial authoritarianism in becoming instantiated in particular legal orders'. ${ }^{71}$ Nevertheless, our defence of liberal constitutional law, in its pure and universal form, must offer more than an

\footnotetext{
$70 \mathrm{n} 1$ above, at xi.
}

71 ibid. 
external standard by which to criticise a particular political arrangement or tradition: it must be a guide for interpretation, assisting us to resolve uncertainties and inconsistencies - even to reconsider what is apparently well-established - in the light of our grasp of what constitutional justice actually requires. Can we really denounce as authoritarianism what is commended by the truth (as we understand it) about the liberal constitution implicit, if only half-recognised, in the daily public rhetoric of democratic governance?

Since texts, especially abstract constitutional provisions, often give ambiguous instructions, and since history is always contested, and precedent always in the process of evolution and refinement, scope for interpretation is never absent; and we should surely be the more reluctant to accept divergence between theory and practice the graver the injustice we have to countenance in consequence. There are arguably standards of legality and decency that, at a certain stage of political development, so strongly underpin the legitimacy of the legal order that their violation involves a form of self-contradiction (like Fuller's hapless Rex, incapable despite his best endeavours of making law). ${ }^{72}$ The close interdependence, within Brudner's own work, of political theory and legal practice should cause us to mark - indeed celebrate - the permeability of the division between the actual and the ideal. The former is always groping towards the latter in the process of discovering its own essential nature. ${ }^{73}$

\footnotetext{
72 n 39 above, 33-41.

${ }^{73}$ Cf L.L. Fuller, The Law in Quest of Itself (Boston: Beacon Press, 1966). See also N. Simmonds, Law as a Moral Idea (Oxford: Oxford University Press, 2007).
} 